\title{
POTENSI PENGEMBANGAN INOVASI DESAIN PRODUK KRIYA KUKM INDONESIA DI ERA INDUSTRI KREATIF
}

\author{
Agung Wicaksono
}

\begin{abstract}
ABSTRAK
Inovasi desain produk kriya dapat dilakukan mulai dari pembuatan konsep perancangannya yang mengacu pada perubahan konsumennya. Produk kriya yang memiliki basis budaya dalam komunitas masyarakat tradisi sangat dibebani oleh nilai-nilai filosofis. Perubahan desain produknya sangat evolutif atau cenderung sangat lambat dan meiliki polapola tertentu. Produk kriya yang dihasilkan sebagai komoditas untuk memenuhi kebutuhan konsumen cenderung berjalan relatif lebih dinamis. Kunci utama perubahan terletak pada SDM pelakunya yang memiliki kemauan dan keterampilan untuk menginovasi desain produk supaya memiliki nilai tambah yang lebih baik lagi. Bangsa Indonesia memiliki modal untuk membuat perubahan pada desain produk kriyanya. Keterbukaan terhadap informasi dan warisan budaya adiluhung merupakan dua faktor penting terjadinya inovasi pada desain produk kriya.
\end{abstract}

Kata kunci : inovasi desain, produk kriya, industri kreatif

\section{PENDAHULUAN}

Produk Kriya sebagai produk budaya dapat dilacak dari sisi sejarah perkembangannya. Pada awalnya produk kriya merupakan alat atau perabot yang berfungsi untuk memenuhi atau membantu manusia dalam memenuhi kebutuhan hidup sehari-hari. Produk kriya sebagai produk budaya juga dapat digunakan untuk menjelaskan ide dan aktivitas manusia di suatu tempat serta waktu tertentu menurut konteks budayanya. Seiring perjalanan waktu, kehidupan sosial budaya masyarakat di Indonesia berkembang, ini secara jelas dapat dilihat dari pembentukan strukturnya. Adat istiadat yang merupakan wujud dari nilai atau norma dan institusi kemasyarakatan merupakan elemen pembentuk tatanan sosial masyarakat menuju kemapanan tradisi . Tatanan sosial dapat diketahui karakternya dari norma untuk mengatur keharmonisan dalam masyarakat. Khususnya di Indonesia, norma-norma secara filosofis banyak terekspresikan pada visualisasi ornamentik dan bentuk produk kriya.

Menurut Soedarso Sp. (2006: 107), bahwa kriya atau crafts memiliki ciri khas sesuatu yang dibuat dengan tangan, biasanya sangat dekoratif atau indah secara visual, dan seringkali merupakan benda pakai. Produk kriya dapat dibuat dengan mesin sepanjang dalam proses pembuatannya tidak terlepas dari

\footnotetext{
* Agung Wicaksono, (agung_w@yahoo.com), Staf Pengajar Program studi Kriya Seni, Jurusan Kriya, Fakultas Seni Rupa, Institut Seni Indonesia Yogyakarta.
} 
pengendalian pembuat secara mutlak. Misalnya penggunaan alat-alat bantu seperti gergaji mesin, mesin jahit, mesin finishing, dan sebagainya. Penggunaan mesin otomatis yang dapat diprogram untuk mengerjakan semua pekerjaan dengan pengawasan sistem sensor otomatis tidak dapat dikategorikan produk kriya. Produk semacam ini lebih tepat jika dimasukkan kategori produk manufaktur.

Pada kasus perkembangan produk kriya saat ini, kebutuhan pasar sangat mendominasi niat perajin untuk membuat produk yang mudah terjual. Terdapat dua nilai yang dibutuhkan oleh konsumen terhadap produk kriya, yaitu kebutuhan estetik dan fungsi. Di Indonesia perkembangan produk kriya tidak terlepas dari perkembangan industri pariwisata. Pada tahun 1980-an mulai terasa dampak dari industri pariwisata yang membutuhkan produk kriya untuk keperluan cindera mata. Saat ini terjadi pergeseran besar pada perkembangan produk kriya terutama pada tujuan pembuatan produk kriya di masyarakat. Masyarakat pelaku usaha di bidang ini menjadi produsen untuk kebutuhan pasar dalam dan luar negeri. Produk kriya menjadi komoditas penting bagi perdagangan produk kriya, artinya masyarakat menjadi pabrik besar bagi produk-produk kriya. Produk-produk kriya tidak sekedar memenuhi kebutuhan industri pariwisata tetapi juga memenuhi permintaan sektor-sektor industri lainnya.

Selama ini terdapat dua strata sosial yang membedakan produk kriya, yaitu budaya agung (high culture) yang biasanya muncul dari penghayatan estetik yang mendalam (politesse) dan dikerjakan dengan craftmanship tinggi. Jika produk kriya muncul dari masyarakat tradisi, maka dimungkinkan akan tercipta karya-karya klasik, seperti batik tulis halus, kain songket, perhiasan, dan sebagainya. Di samping itu ada produk kriya yang dihasilkan dari budaya alit (folk culture), sebagian besar berasal dari budaya rakyat. Produk ini lebih dominan dibuat untuk memenuhi kebutuhan sehari-hari. Produk ini tidak terlalu dibebani dengan nilai-nilai filosofi dan pengerjaannya tidak sehalus produk kriya dari budaya agung. Meskipun demikian tidak menutup kemungkinan digunakannya unsur estetika dan dan craftmanship. Contoh produk kriya ini antara lain batik cap, ukir-ukiran pada furniture, gerabah, dan sebagainya (Soedarso Sp., 2006: 113 ).

Konsep industri kreatif merupakan industri budaya (culture industries) yang menawarkan terobosan baru dalam menggali potensi-potensi budaya lokal untuk basis pembuatan produk inovatif. Industri kreatif di Indonesia memberikan banyak kontribusi secara ekonomi dan penyerapan tenaga kerja (Agung Wicaksono, 2009:208). Pada era kepemimpinan Presiden Joko Widodo, urusan ekonomi kreatif tidak lagi di bawah suatu kementerian seperti pada era pemerintahan sebelumnya. Kemungkinan urusan ini akan ditangani oleh lembaga setingkat badan. Meskipun demikian kegiatan industri kreatif tetap berjalan di tengah masyarakat yang didukung oleh komunitas-komunitas kreatif di masingmasing daerah. Kota-kota di Bali dan Jawa masih menjadi barometer kemajuan industri kreatif Indonesia. Jika disebutkan kata industri maka hal tersebut selalu terkait dengan pasar. Pada hakekatnya 
kegiatan industri adalah mata rantai antara produsen dan pasar atau konsumen. Pada tulisan ini penyebutan pasar berarti juga terkait erat dengan penyebutan istilah industri kreatif.

\section{Inovasi Desain Produk Kriya}

Inovasi desain produk kriya mengandung pengertian perubahan desain (material, bentuk/visual, fungsi, dan teknologi) untuk tujuan tertentu, misalnya memenuhi kebutuhan konsumen yang selalu mengalami perubahan dalam jangka waktu tertentu. Perubahan desain dilakukan dengan berbagai alasan, antara lain perubahan perilaku konsumen, perkembangan kompetitor, penemuan teknologi, dan perkembangan nilai estetik. Daya saing produk kriya ditentukan oleh ketajaman produsen untuk mengantisipasi perubahan-perubahan cepat yang terjadi di pasar.

Perubahan ini menyebabkan terjadinya siklus dalam inovasi desain. Siklus ini lazim dikenal dengan istilah umur desain produk yang dimulai dari fase muncul, berkembang, puncak (mature), penurunan, dan hilang. Banyak produsen produk kriya berkompetisi pada inovasi desain dan menyebabkan perlunya pengembangan inovasi pada desain produk kriya. Produk kriya yang menjadi salah satu komoditas penting di Indonesia memiliki tantangan cukup besar dalam mengembangkan daya saing produknya di pasar internasional. Di dalam negeri pun mereka juga menghadapi kompetisi ketat dengan produk-produk impor dari beberapa negara di Asia. Meskipun demikian, peluang produk kriya untuk meningkatkan kesejahteraan masyarakat masih cukup besar. Inovasi desain merupakan ujung tombak peningkatan daya saing disamping faktor-faktor lain seperti penguatan akses permodalan, perbaikan sistem produksi, dan peningkatan sistem distribusi dalam pemasaran.

Produk kriya yang dibuat oleh perajin dalam kawasan sentra kerajinan memiliki karakter khas dalam pola inovasi desainnya. Mereka banyak yang melakukan perubahan atau inovasi desain secara evolutif, ini berakibat pada perubahan desain yang relatif sangat lambat. Desain produk kriya mengalami proses perubahan secara evolutif, atau perubahan tersebut dilakukan dalam rentang waktu yang sangat panjang. Pola ini banyak terdapat pada kawasan sentra yang memiliki karakter komunal dan kolegial. Komunal berarti berkeompok yang saling mempengaruhi satu dengan lainnya dan kolegial berarti memiliki relasi-relasi tertentu pada struktur komunitasnya. Menurut Soerjono Soekanto (2010:54), bahwa terdapat dinamisasi masyarakat yang disebabkan interaksi anggota-anggotanya. Di dalam masyarakat tersebut terjadi proses sosial yang dapat menyebabkan terjadinya perubahanperubahan pola kehidupan sosial.

Perubahan evolutif desain produk kriya disebabkan dua hal, yaitu beban psikologis masyarakat terhadap simbol dan makna serta sistem pembelajaran masyarakat perajin. Faktor pertama dapat dijelaskan bahwa produk kriya tertentu yang masih terkait dengan kesakralan atau simbol status sosial masyarakat tradisional masih dibebani dengan nilai-nilai filosofis atau makna-makna simbolik. Karakter baku (pakem) sangat dijunjung tinggi oleh 
komunitas atau masyarakatnya. Elemen desain yang banyak dibakukan menjadi pakem sebagian besar adalah motif-motif ornamentik. Motif-motif tersebut memiliki daya ekspresi nilai-nilai yang dijunjung tinggi dalam masyarakat tradisional. Faktor kedua terjadi karena sistem pembelajaran perajin masih mengandalkan sistem duplikasi atau peniruan terhadap produkproduk baru yang memiliki daya jual lebih baik. Masyarakat perajin memiliki rasa takut untuk merubah desain-desain tersebut karena beban psikologis dan perasaan takut untuk berspekulasi terhadap kemauan pasar.

Produk-produk kerajinan yang memiliki nilai kesakralan dalam penggunaannya cenderung mengalami pengurangan secara jumlah untuk penggunaan dalam kehidupan (operasional sehari-hari). Sebagai contoh : keris yang pada awalnya memiliki fungsi sebagai senjata tikam, sekarang lebih banyak dipakai untuk keperluan spiritual magis dan atribut status sosial di tengah masyarakat. Harga produk kriya semacam ini cenderung mahal, jika dibandingkan dengan produkproduk kriya yang tidak dibebani berbagai macam ketentuan yang mengacu pada nilainilai tradisi.

Kunci keberhasilan inovasi desain terletak pada faktor kapasitas sumber daya manusia. Secara internal, kapasitas SDM (pelaku usaha kerajinan) memegang kendali utama dalam inovasi desain. Kemauan untuk berkembang dengan cara melakukan eksperimen-eksperimen kebaruan konsep desain produk kriya adalah langkah awal yang diperlukan untuk keberlanjutan inovasi desain. Pengembangan kapasitas perajin dapat dilakukan dengan proses panjang pembelajaran dan pengayaan pengalaman praksis. Wawasan dan keterampilan perajin secara simultan didorong untuk tidak berhenti menghasilkan karya-karya kriya yang unggul dalam konsep dan kualitasnya.

Faktor lain yang mendorong terjadinya inovasi desain adalah tuntutan terhadap keberagaman kebutuhan konsumen. Tuntutan konsumen ini perlu dikomunikasikan dengan baik agar perajin memiliki kesadaran atau sensitivitas terhadap kebutuhan konsumen. Perbaikan pada akses informasi pasar berakibat pada semakin luasnya wawasan pelaku usaha kerajinan. Media-media yang dimiliki perajin merupakan simpul-simpul terjadinya proses komunikasi antara konsumen dan produsen. Selama ini sebagian besar perajin memiliki posisi pasif dalam hal akses informasi. Perubahan desain jarang dilakukan jika konsumen tidak secara langsung meminta kepada perajin untuk melakukannya.

Hal lain yang diperlukan oleh pelaku usaha kerajinan adalah pemahaman dan penerapan manajemen desain. Karakter perajin yang melakukan segala hal dalam pengelolaan usahanya menyebabkan mereka kehilangan energi untuk melakukan inovasi desain. Penyadaran terhadap perilaku usaha perajin sangat diperlukan agar mereka tidak kehilangan momentum dalam melakukan inovasi yang tujuannya adalah meningkatkan daya saing di pasar. Inovasi desain masih dianggap kegiatan yang tidak menguntungkan dari sisi pencapaian keuntungan. Langkah pragmatis dipandang lebih menguntungkan daripada langkah yang memiliki nilai strategis jangka menengah dan panjang. 
Inilah faktor yang mengkhawatirkan bagi keberlangsungan kerajinan Indonesia dalam jangka panjang dari sisi ekonomi dan konservasi.

\section{Peningkatan Kualitas Produk Kriya}

Kualitas produk kriya ditentukan oleh kualitas ide atau tema, bahan, teknik/craftmanship, dan finishing. Kapasitas ketrampilan SDM/perajin sangat menentukan tingkat kualitas produk kriya. Ini akan tercermin dari tingkat kerumitan pengerjaan produk kriya. Bahan berkualitas berpengaruh pada penampilan produk kriya di samping memberikan kemudahan pada proses pengerjaan. Ukuran kualitas adalah kesesuaian antara permintaan konsumen dengan spesifikasi produk yang dihasilkan pelaku usaha kerajinan. Produk kerajinan berbeda dengan produk manufaktur yang memiliki tingkat keseragaman tinggi. Produk manufaktur sangat tergantung pada kerja-kerja yang dilakukan mesin-mesin produksi dengan tingkat akurasi lebih tinggi. Produk kerajinan merupakan hasil karya tangan-tangan terampil yang memiliki tingkat akurasi berbeda-beda. Nilai kualitas produk kerajinan terletak pada nilai rasa perajin yang terekspresikan pada elemenelemen produk kerajinan. Nilai craftmanship akan terlihat pada kerumitan proses produksi yang menghasilkan produk dengan tingginya tingkat kesulitan dalam pengerjaan. Sebagai contoh dapat dilihat pada produk kriya Indonesia yang memiliki tingkat kesulitan tinggi dalam pengerjaan dan sulit tertandingi oleh kemampuan mesin-mesin produksi.

Peningkatan kualitas biasanya diiringi dengan peningkatan biaya produksi. Dalam sebuah usaha kerajinan, hal ini perlu diperhatikan agar harga produk dapat terjangkau oleh segmen pasar yang dibidik. Konsumen yang memiliki tingkat sensitifitas pada harga tentu akan memiliki pertimbangan utama pada kenaikan harga produksi. Pada produk kriya dengan desain sederhana, atau banyak diproduksi oleh perajin memiliki kompetisi pada harga yang sangat tinggi. Meskipun demikian peningkatan kualitas menjadi prioritas utama untuk memenangkan pasar. Batik tulis yang dikerjakan oleh tangan-tangan terampil pembatik selama berbulan-bulan sangat besar kemungkinannya memiliki pangsa pasar kecil. Sementara batik cap memiliki pangsa pasar yang lebih luas karena faktor harga produksi yang lebih rendah.

Aspek teknologi tidak dapat dilepaskan dari proses pembuatan produk kriya yang menginginkan tercapainya kualitas produk. Teknologi dapat membantu perajin untuk memperoleh hasil yang berkualitas karena terbantu dalam kemudahan pancapaian teknik-teknik tertentu. Misalnya, kualitas ukiran sangat dipengaruhi oleh kualitas material alat ukirnya (tatah). Logam yang berkualitas tentu memudahkan bagi pembuat produk kriya untuk mewujudkan rancangan motif dengan sempurna. Di Indonesia belum banyak dikembangkan kemitraan antara komunitas peneliti dengan perajin untuk menghasilkan inovasi-inovasi yang dapat meningkatkan kualitas produk. Perajin banyak bereksperimen karena permintaan konsumen dengan metode coba-coba (trial and error). Biasanya hasil eksperimen tersebut tidak memiliki dampak besar pada perolehan profit karena tidak pernah dilindungi dan dihargai sebagai hasil 
penemuan. Christopher Jones (1979:19) menyebutkan bahwa kelemahan perajin adalah menggunakan metode trial and error pada pembuatan produk kriya. Perajin juga jarang yang dapat menjelaskan secara grafis dan argumentatif terhadap keputusan-keputusan yang diambil pada saat proses produksinya. Perkembangan produk kriya berjalan secara evolutif sehingga sering kurang cepat mengantisipasi perubahan selera konsumen.

Penataan sistem produksi juga merupakan faktor yang dapat meningkatkan kualitas produk. Pada sistem produksi yang baik akan terjadi pengurangan kesalahan produksi, biaya produksi bisa dikontrol dengan baik, dan kapasitas produksi juga dapat ditingkatkan. Kunci utama pada kualitas produk adalah konsistensi produk, oleh karena itu pengendalian kualitas harus melekat pada manajemen produksi. Skala usaha perajin yang sebagian besar pada tingkat mikro dan kecil menyebabkan kesulitan dalam berinvestasi sarana produksi. Sebenarnya usaha pelayanan teknis masih sangat diperlukan oleh perajin untuk menghasilkan produk yang lebih baik. Usaha pelayanan teknis yang dapat mengikuti tuntutan perajin dapat mendorong terjadinya percepatan dalam upaya peningkatan kualitas produk.

Jika peningkatan kualitas produk tidak menjadi prioritas dalam strategi usaha kerajinan maka dapat dipastikan perajin akan kehilangan pangsa pasar. Kompetisi yang ketat menyebabkan tuntutan pada peningkatan kualitas produk tidak dapat ditunda lagi. Pengalaman dari beberapa sentra kerajinan yang kehilangan pangsa pasar akibat dari penurunan kualitas produk sudah banyak terjadi di Indonesia. Negaranegara di sekitar Asia Selatan dan Tenggara serta Amerika Latin terus melakukan upaya peningkatan kualitas komoditas kerajinannya. Sementara di negara-negara maju dikembangkan industri-industri kerajinan yang memiliki nilai tinggi dan kompatibel dengan produk-produk manufaktur.

\section{Penguatan Branding Produk Kriya}

Nilai craftmanship dalam seni kriya terkait erat antara keterampilan tangan dan penghayatan perajin terhadap alat dan bahan. Keterampilan kriya termasuk juga kepandaian menggunakan peralatan sesuai dengan media yang dipakai. Sebagai contoh perajin ukir kayu sering langsung mengerjakan ukiran pada kayu tanpa menggunakan gambar-gambar pola. Seakan-akan jiwa mereka menyatu dengan alat, bahan, dan metode pengerjaannya. Kebiasaan ini banyak terjadi pada perajin produk kriya tradisi lainnya. Perajin yang mengerjakan sistem produksi seperti ini dimungkinkan karena telah mengerjakan selama bertahun-tahun pada pekerjaan yang sama. Namun juga dapat terjadi pada perajin yang memiliki karakter pekerjaan yang membuat karya kriya dengan tidak merubah kondisi bahan, misalnya ukiran akar kayu. Ukiran akar kayu tergantung dari bentuk akar yang didapat, sulit mengharapkan hasil yang sama untuk beberapa produk.

Keunikan ini tidak akan dapat diterima oleh konsumen jika tidak ada upaya pengenalan produk terhadap konsumen. Sering terjadi konsumen tidak dapat membedakan antara produk kerajinan dengan produk 
manufaktur. Ini terjadi pada salah pengertian terhadap batik oleh masyarakat luas. Tidak jarang terjadi, konsumen membandingkan harga antara batik tulis dengan kain printing bermotif seperti batik. Ketidakmengertian ini menyebabkan terjadinya kerancuan apresiasi terhadap produk kerajinan. Hal serupa juga terjadi pada para perajin yang sering membandingkan karyanya dengan produk manufaktur. Jahitan halus pada produk manufaktur sering dibandingkan dengan jahit tangan pada produk kerajinan. Nilai pada kerajinan tangan berbeda dengan produk manufaktur, karena produk kerajinan tangan dapat mengekspresikan kesungguhan perajin pada karyanya.

Branding adalah upaya untuk membuat persepsi masyarakat agar selalu ingat terhadap suatu produk. Produk kriya yang memiliki kekhasan pada proses produksi dan nilai estetikanya perlu dilakukan upaya pengembangan branding dengan strategi khusus. Upaya pameran merupakan salah satu langkah yang perlu dilakukan. Pameran yang baik adalah pameran yang telah terseleksi dampaknya dan melalui persiapan yang komprehensif. Dengan demikian konsumen atau pasar akan dapat menemukan apa yang mereka inginkan, atau bahkan lebih dari apa yang diinginkan.

Kekurangan pada produk kriya Indonesia adalah narasi yang dapat menjelaskan kepada konsumen tentang produk tersebut. Produk kriya Indonesia adalah produk berbasis pada budaya bangsa. Budaya bangsa Indonesia perlu diperkenalkan atau disebarluaskan ke seluruh dunia agar pasar dapat menerima produk tersebut. Industri kreatif memerlukan penyebarluasan citra kepada khalayak di seluruh dunia. Globalisasi menghasilkan pemahaman lebih mendalam terhadap keanekaragaman budaya semua bangsa.

\section{Modal Budaya}

Produk kriya adalah salah satu hasil kreativitas manusia yang diciptakan dengan tangan untuk memenuhi kebutuhan dasar hidupnya. Manusia diciptakan dengan kemampuan akal dan keterampilannya sehingga mampu belajar dari pengalaman dalam membuat produk kriya dengan menggunakan tangannya sebagai alat utamanya. Pengalaman tersebut semakin memperkaya pengetahuan dan keterampilannya. Tangan-tangan mereka semakin terampil dan dapat merangsang kreativitas dalam menciptakan karya kriya. Keterampilan tangan dan penguasaan teknologi proses, serta pengetahuan material menjadi sarana utama dalam penguasaan teknik kriya secara komprehensif.

Penguasaan teknik kriya berkembang selaras dengan perkembangan pengetahuan terhadap bahan dan alat yang digunakan. Pengenalan karakter bahan mutlak diperlukan dalam mengembangkan inovasi produk. Pengenalan alat dan bahan merupakan salah satu bentuk kearifan lokal (local genius) yang diturunkan secara sistematis pada masyarakat. Inilah bentuk modal budaya yang dapat dikembangkan dari masyarakat. Pengembangan teknik kriya juga dapat dikatakan sebagai salah satu modal budaya yang biasanya diberikan secara turun temurun pada masyarakat tradisi. Pada masyarakat modern, ini dapat 
dilakukan dengan cara belajar baik secara formal maupun non formal.

Budaya dapat dikaitkan dengan kebiasaan yang telah dilakukan berulangulang dalam suatu komunitas atau masyarakat dengan rentang waktu panjang. Aktivitas seperti ini terjadi pada masyarakat tradisi yang masih memegang normanorma yang tertanam di dalamnya. Normanorma tersebut terbentuk karena adanya kolektivitas ide dalam masyarakat yang berkembang menjadi salah satu sarana pengikat di dalamnya. Ide dan aktivitas dapat memunculkan karya-karya, termasuk kerajinan yang menjadi ikon bagi masyarakat pendukungnya.

Kekayaan alam merupakan sumber ide yang paling banyak mempengaruhi masyarakat. Di daerah Singkawang, Kalimantan Barat, banyak masyarakat yang membuat keramik dengan memanfaatkan tanah di sekitarnya. Pengaruh ornamen Cina sangat kental dalam keramik buatannya. Keramik yang dibuat oleh masyarakat Singkawang terdiri dari guciguci besar dengan teknik putar dan glasir. Masyarakat di daerah ini mayoritas terdiri dari masyarakat yang berasal dari etnis Cina, tentu mereka membuat produk kriya sesuai dengan latar belakang budayanya. Inilah kekayaan karya kriya di Indonesia yang bermula dari modal budaya setempat.

Tanah liat merupakan bahan baku keramik, baik untuk keramik bakaran rendah (earthen ware) maupun bakaran tinggi (stone ware). Keramik termasuk produk kriya yang memiliki umur sudah sangat tua. Manusia membuat keramik karena adanya interaksi dengan tanah liat dan air. Tanah liat memiliki sifat mudah dibentuk dan akan mengeras jika mengalami perlakuan pada suhu dan kelembabannya. Pengalaman ini diteruskan oleh nenek moyang untuk menghasilkan benda-benda guna, seperti tempat air atau alat memasak. Teknik-teknik pembuatannya mengalami perkembangan yang cukup beragam. Jika dilihat pada teknik keramik yang dikembangkan pada beberapa daerah terdapat kekhasan masing-masing. Teknik putar banyak dilakukan oleh perajin dari Singkawang dan Pleret. Di Yogyakarta, khususnya Kasongan, Bantul, banyak menggunakan teknik pilin dan tempel untuk membuat produk-produk keramik berbentuk binatang. Perempuanperempuan di Bayat, Klaten, Jawa Tengah, banyak membuat keramik dengan cara diputar dengan kemiringan tertentu. Sekarang banyak dikembangkan teknik cetak dalam pembuatan keramik yang berakibat pada semakin bervariasinya bentuk keramik.

Demikian juga yang terjadi pada produk-produk kriya lainya, biasanya perajin mengembangkannya terkait dengan ketersediaan bahan baku dan kebiasaankebiasaan (adat budaya) yang ada di sekitarnya. Inilah modal budaya yang dapat dijadikan kegiatan yang bernilai ekonomi. Latar belakang budaya merupakan nilai tersendiri bagi hasil karya masyarakat Indonesia. Pada saat ini banyak produkproduk dari negara-negara maju yang terinspirasi dari nilai-nilai dan artefak budaya Nusantara. Kriya kontemporer banyak mengambil nilai-nilai budaya lokal untuk dihadirkan menjadi karya masa kini yang dapat memenuhi kebutuhan masyarakat.

Pengembangan modal budaya dapat dikaitkan dengan pariwisata seperti 
yang telah dilakukan di Bali. Sejarah perkembangan kerajinan Indonesia dapat menembus pasar dunia tidak terlepas dari perkembangan pariwisata di Indonesia. Pariwisata secara langsung membawa dampak pada kedatangan pembeli dari luar negeri. Mereka membeli kerajinan Indonesia untuk dijual lagi ke negara lain. Pulau Bali yang merupakan tujuan utama pariwisata mancanegara juga merupakan simpul pemasaran produk kerajinan Indonesia ke pasar internasional. Gangguan yang terjadi pada pariwisata di Bali langsung berdampak pada penurunan omset kerajinan Indonesia. Hal ini pernah dirasakan pada beberapa tahun yang lalu ketika terjadi peristiwa Bom Bali. Banyak wisatawan mancanegara yang juga buyer potensial pergi keluar dari Indonesia.

$$
\text { Ikon-ikon budaya seperti }
$$

Borobudur turut mendorong optimalisasi modal budaya untuk menghasilkan karyakarya kriya dengan estetika tinggi. Keunikan bangunan ini dapat menginspirasi perajinperajin ukir batu di sekitar Borobudur menghasilkan produk-produk kerajinan dengan nilai jual tinggi. Beberapa negara di Eropa dan Amerika banyak memesan hasil karya mereka. Kepandaian mengukir batu yang berasal dari proses vulkanik Gunung Merapi diteruskan oleh perajin di wilayah ini. Tidak hanya masyarakat di sekitar Borobudur yang mampu mengambil kesempatan membuat karya ukir batu, tetapi banyak perajin lainnya yang mengambil ikon-ikon Borobudur sebagai ide pembuatan produk kerajinannya. Tidak kalah indahnya perajin perak di Kotagede membuat kerajinan perak dengan teknik filigri (susunan kawat-kawat perak) berbentuk maket Borobudur. Perajin keramik di Kasongan juga membuat replika kepala Budha dari tanah liat dan dibakar menjadi keramik.

Kehidupan masyarakat Kalimantan tidak lepas dari anyaman rotan yang banyak tumbuh di hutan-hutan tropisnya. Masyarakat Kalimantan telah mengenal pembuatan tas atau wadah untuk membawa barang-barang yang materialnya dari rotan. Rotan dianyam dengan motifmotif indah yang terinspirasi dari flora dan fauna setempat. Di rumah-rumah mereka juga banyak terdapat anyaman rotan yang dijadikan alas duduk (tikar). Benda-benda tersebut digunakan oleh masyarakat Kalimantan dalam kehidupan sehari-hari. Produk mereka ternyata banyak disukai oleh konsumen dari berbagai daerah di dalam dan luar negeri. Menurut Yekti Maunati (2006:272), bahwa masyarakat Dayak berubah menjadi produsen barangbarang cindera mata yang berasal dari barang-barang tradisional yang mereka pergunakan sehari-hari. Mereka memiliki kegiatan ekonomi memproduksi cindera mata disamping pergi ke ladang. Banyak warga dayak yang bermukim di Malaysia membeli cindera mata tersebut sebagai atribut mereka untuk menunjukkan identitasnya. Hal seperti ini disebut komodifikasi kebudayaan yang memiliki ekses positif dan negatif.

Jika pengembangan produk kriya dilakukan dengan berbasis pada budaya lokal, maka sulit bagi negara lain untuk membuat hal yang sama dengan perajin Indonesia. Identitas lokal tidak mungkin diambil oleh negara lain. Meskipun kekayaan budaya Indonesia sangat melimpah, namun perlu dilakukan upaya komprehensif agar masyarakat dunia dapat 
melihat potensi ini. Modal budaya adalah kekayaan yang terus menginspirasi perajin Indonesia untuk berkarya. Pasar industri kreatif mengharapkann hadirnya produkproduk berbasis budaya lokal disertai dengan narasi-narasi yang membangun kesadaran dan pencitraan positif.

\section{PENUTUP}

Inovasi produk kriya merupakan kekuatan kompetitif yang diperlukan untuk meraih pangsa pasar dalam dan luar negeri. Produk kriya Indonesia masih menghadapi tantangan pada ketersediaan SDM yang mampu menginovasi desainnya untuk dapat memenuhi selera pasar. Modal budaya dan crafmanship adalah dua hal yang mampu menjadi faktor pendukung untuk pencitraan produk kriya berbasis budaya lokal yang diperlukan pada era industri kreatif.

\section{DAFTAR PUSTAKA}

Jones, Christopher J., Design Methods: Seed of Human Being, John Wiley \& Sons Ltd., London, 1979.

Maunati, Yekti, Identitas Dayak Komodifikasi dan Politik Kebudayaan, LkiS, Yogyakarta, 2006

Soedarso Sp., Trilogi Seni: Penciptaan Eksistensi dan Kegunaan Seni, BP ISI Yogyakarta, Yogyakarta, 2006.

Soerjono, Soekanto, Sosiologi Suatu Pengantar, Rajawali Pers, Jakarta, 2010.
Wicaksono, Agung, "Eksistensi Seni Kriya Indonesia di Era Gelombang Ekonomi Kreatif", dalam Sri Kresnanto, dkk. (ed.), Seni Kriya dan Kearifan Lokal dalam Lintasan Ruang dan Waktu, BIDISI, Yogyakarta, 2009. 